\title{
PROCESO CONSTRUCTIVO DEL CLAUSTRO DE SAN MILLÁN DE LA COGOLLA POR JUAN PÉREZ DE SOLARTE
}

Aurelio A. Barrón García

Universidad de Cantabria

RESUMEN: Juan Pérez de Solarte partió de un proyecto de Juan de Vallejo para el claustro de San Millán (1549-1559), pero le incorporó modificaciones sugeridas por la Orden benedictina y por ello se asemeja tanto al del monasterio de Irache. Solarte debió de realizar también el coro alto de la iglesia, y en la talla de algunas partes del claustro pudo colaborar el imaginero Juan de Villarreal.

Palabras clave: Arquitectura, Renacimiento, claustro, Castilla, La Rioja, San Millán de la Cogolla, Juan Pérez de Solarte, Juan de Villarreal, Juan Martínez de Mutio.

\section{CONSTRUCTION PROCESS OF THE CLOISTER OF SAN MILLÁN DE LA COGOLLA BY JUAN PÉREZ DE SOLARTE}

ABSTRACT: Juan Perez de Solarte continued a design of Juan de Vallejo for the cloister of St. Millán de la Cogolla (1549-1559). Nevertheless, he incorporated some changes suggested by the Benedictine Order; that's the reason of the similarities between the cloisters of St. Millán and Irache monasteries. Solarte must also do the high church choir, and the sculptor Juan de Villarreal could collaborate on the sculpture of the cloister.

Keywords: Architecture, Renaissance, cloister, Castille, La Rioja, San Millán de la Cogolla, Juan Pérez de Solarte, Juan de Villarreal, Juan Martínez de Mutio.

Los datos básicos sobre la autoría de Juan Pérez de Solarte y la construcción del claustro de San Millán de la Cogolla se conocen', pero el hallazgo de los plei-

1. RUIZ GALARRETA, J. M. y ALCOLEA, S., Logroño y su provincia. Barcelona 1962, p. 117; PEÑA, J., Páginas Emilianenses. San Millán de la Cogolla 1980, pp. 199-201; MOYA VAL- 
tos que durante años mantuvo el autor con el monasterio permite aportar bastantes noticias inéditas y reconstruir con detalle el proceso constructivo. Los pleitos comenzaron en 1553, poco antes de la conclusión de la monumental portada que comunica el claustro con la iglesia. Seguramente, por entonces, estaban levantados los muros perimetrales del claustro y dos capillas de diecisiete claves, delante de las sepulturas del tramo norte, que se ofrecieron como modelos para el cierre del conjunto. Había que pagar al cantero y el monasterio inició un pleito ya que estaba disconforme con la valoración que en 1549 habían acordado sobre el alcance de las rentas de Badarán, beneficios del monasterio que permitieron cerrar las bóvedas de la iglesia y levantar el claustro.

Juan Pérez de Solarte (fallecido en $1566^{2}$ ) aparece por primera vez el 7 de diciembre de 1538, vinculado a la obra de la iglesia del monasterio y mencionado como criado de Juan Martínez de Mutio. Mutio lo presentó como uno de sus fiadores en la obra del abovedamiento de la iglesia del monasterio de Yuso de San Millán de la Cogolla3. Para entonces, Solarte estaba ya casado con María Ibáñez de Mutio, hermana de Juan. Como criado de Mutio, Solarte trabajó en la obra de los abovedamientos de la iglesia y así lo recordó en 1551 Pedro Mar-

GAÑÓN, J. G., Arquitectura religiosa del siglo XVI en La Rioja Alta. Logroño 1980, T. I, p. 102; BARRIO LOZA, J. A. y MOYA VALGAÑÓN, J. G., "Los canteros vizcaínos (1500-1800). Diccionario biográfico", Kobie 11 (1981), p. 252; CALATAYUD FERNÁNDEZ, E., Arquitectura religiosa en La Rioja Baja: Calahorra y su entorno (1500-1650). Logroño 1991, vol. I, p. 563; ARRUÉ UGARTE, B. y MARTÍNEZ GLERA, E., "Valoración del patrimonio arquitectónico del monasterio de San Millán de la Cogolla de Yuso (La Rioja)", Berceo 133, (1997), pp. 124 y 133 ; MOYA VALGAÑÓN, J. G., "La iglesia de San Millán de la Cogolla de Yuso", Los Monasterios de San Millán de la Cogolla. VI Jornadas de Arte y Patrimonio Regional. Logroño 2000, pp. 80 y 89; PECIÑA RUIZ, C., "Intervenciones e intentonas clasicistas entre 1570 y 1640 en San Millán de la Cogolla. El antiescorial de La Rioja", Los Monasterios de San Millán..., p. 250; ARRÚE UGARTE, B., "Entorno y dependencias conventuales del monasterio benedictino de San Millán de la Cogolla de Yuso a mediados del siglo XVII", Actas de las VII Jornadas de Arte y Patrimonio Regional. Logroño 2002, p. 212; ARRÚE UGARTE, B., "El sistema hallenkirchen en La Rioja: de los modelos conservados al singular ejemplo de San Millán de la Cogolla", en LACARRA DUCAY, M. ․ C. (coord.), Arquitectura religiosa del siglo XVI en España y Ultramar. Zaragoza 2004, p. 124; SAN MARTÍN ASCACÍBAR, L., La actividad artística en La Rioja durante el siglo XVI. Logroño 2005; ARRÚE UGARTE, B. y REINARES FERNÁNDEZ, O., "Construcción, ruina, reconstrucción y conservación de la iglesia de San Millán de la Cogolla de Yuso (La Rioja)", Actas del Cuarto Congreso Nacional de Historia de la Construcción. Cádiz 2005, p. 90; MOYA VALGAÑÓN, J. G., "Arquitectura religiosa”, en MOYA VALGAÑÓN, J. G. (dir.), Historia del Arte en La Rioja. El siglo XVI. Logroño 2007, pp. 167, 175 y 180.

2. Posiblemente antes del 3 de agosto de 1566 y, con seguridad, antes del 10 de noviembre de 1566; LECUONA, M. de, "La catedral de Calahorra (notas histórico-arqueológicas)", Berceo 2 (1947), p. 98; CALATAYUD FERNÁNDEZ, E., Arquitectura..., T. I, pp. 564 y 638.

3. MOYA VALGAÑÓN, J. G., Arquitectura religiosa..., T. II, p. 21. Se especifica que Solarte era "estante" en el valle de San Millán. Otro de los fiadores fue Martín Ibáñez de Mutio, estante en Santa Coloma. El 28 de junio de 1540 el abad puso solemnemente la última piedra que cerraba las bóvedas de la iglesia; PEÑA, J., Páginas..., pp. 199-200. 
tínez de Zurbano, criado también de Juan Martínez de Mutio. Zurbano residía en Fuenmayor al declarar que cuando trabajaba en San Millán supo por Mutio y Solarte que Martín Ibáñez de Mutio había tomado la obra de la iglesia de Santa Coloma ${ }^{4}$. Eran años en los que Martínez de Mutio tenía tantas obras contratadas que tuvo que cederlas a varios de sus criados, familiares y colaboradores ${ }^{5}$.

Solarte ha de ser el maestro cantero Juan Pérez que, estante en San Asensio -donde se ubican unas conocidas canteras-, testificó, el 14 de septiembre de 1541, en el contrato de Juan Martínez de Mutio con el cabildo y concejo de Huércanos para continuar la obra de la iglesia de San Pedro que había queda-

4. MOYA VALGAÑÓN, J. G., Arquitectura religiosa..., T. II, p. 30.

5. Juan Martínez de Mutio (ca. 1498 según declaró en 1551 y fallecido el 28 de febrero de 1558) fue un cantero muy activo y muy capaz, pero su testamento demuestra que tuvo una intensa actividad comercial y prestamista en su tierra vizcaína; ARCHV, R. Ejecutorias, C.1027.32. Como regentaba un próspero negocio en Aulestia y no tenía hijos, pudo querer desprenderse de los contratos de cantería y cederlos o confiarlos a familiares y colaboradores: Juan de Acha en el coro de Nájera y su cuñado Pérez de Solarte en la obra de San Millán. A su hermano Martín Ibáñez de Mutio le cedió las obras de Santa Coloma y Huércanos. Tras la muerte de Juan Ortiz de San Asensio, Juan Martínez de Mutio recontrató, en 1541, la obra de la iglesia de Huércanos pero, a continuación, la cedió a Martín. Lo mismo hizo con la obra de Santa Coloma que el abad de Nájera le había ofrecido a Juan de Acha aunque éste renunció a ella por complacer a Juan Martínez de Mutio del que había sido criado con anterioridad; MOYA VALGAÑÓN, J. G., Arquitectura religiosa..., T. II, p. 31. Juan Martínez de Mutio era hijo de Juan Martínez de Mutio el Viejo, mercader y cantero que estuvo casado con Ochanda de Mutio y posiblemente después con otra mujer con la que tenía en 1527 a Marina de Arbomagorta o Albinagorta; ARCHV, R. Ejecutorias, C.1027.32. Como Juan Martínez de Mutio hijo -el arquitecto de las bóvedas de San Millán- se casó el 10 de febrero de 1527 con María Ochoa de Uribarri, es casi seguro que al padre correspondan las primeras labores documentadas en la iglesia de Pedroso de 1515 a 1522; MOYA VALGAÑÓN, J. G., "La iglesia de Pedroso (La Rioja) en el siglo XVI", en ÁLVARO ZAMORA, M. ․ I., LOMBA SERRANO, C., PANO GARCÍA, J. L. (coord.), Estudios de historia del arte. Libro homenaje a Gonzalo M. Borrás Gualis. Zaragoza 2013, pp. 575 y 580. Martín Ibáñez de Mutio (ca. 1507 y fallecido poco antes del 25 de julio de 1557) se casó con María Sáenz de Olea con la que tuvo a Magdalena de Mutio casada con Diego de Arteaga. De un segundo matrimonio de Martín, en 1549, con Sancha u Osana de Zubiaur nació María de Zubiaur -también llamada María Ibáñez de Mutio- que no fue reconocida como legítima por la justicia por haber nacido antes de 1553, fecha en la que el matrimonio obtuvo dispensa de consanguineidad. Por ello no pudo cobrar lo que la habría pertenecido de los bienes gananciales de lo obrado por su padre en las iglesias de Azofra, Arenzana de Arriba, Sojuela, Bezares, Manjarrés y Santa Coloma; ARCHV, R. Ejecutorias, C.983.27, C.1178. 38, C.1181.47. Juan Martínez de Mutio tuvo dos hermanas homónimas: María Ibáñez de Mutio, esposa de Juan Pérez de Solarte, y María Ibáñez de Gorostiaga, esposa de Juan Ortiz de Gorostiaga, que en 1558 reclamó su parte en la herencia de su hermano Juan. Para enredar aún más los datos de esta familia existe otro Juan Martínez de Mutio que declaró en 1554 que era cantero, tenía 35 años y era hermano de Juan Martínez de Mutio, el afamado arquitecto de San Millán; ARCHV, Pl. Civiles, Moreno (F), C.807.2. Sin embargo, este segundo Juan murió antes que el conocido arquitecto quien mencionó a su hermano dos veces como difunto en su testamento de 23 de febrero de 1558; ARCHV, R. Ejecutorias, C.1027.32. 
do sin maestro por la muerte, en 1539, de Juan Ortiz de San Asensio, primer contratante de esta iglesia en septiembre de 1533․ Años después, en julio de 1546, Solarte era habitante de Anguiano cuando Juan Martínez de Mutio, que entonces atendía la iglesia de Fuenmayor, lo presentó como fiador del concierto para la construcción de las últimas seis capillas de la iglesia de Briones, además del coro y de la torre ${ }^{7}$. En la misma fecha de 1546 Solarte intervino en la tasación de la obra realizada en el claustro del monasterio de Irache (Navarra) -diez capillas que incluían la panda norte- por Martín de Oyarzábal, que había fallecido el año anterior $^{8}$. Pérez de Solarte acudió Ilamado por el abad que podía conocerlo por su intervención en la obra de la iglesia de San Millán de la Cogolla de la misma orden benedictina ya que nos parece que, además de su participación en el abovedamiento de la iglesia, la obra del coro alto de San Millán se puede relacionar con él ${ }^{9}$. Los abovedamientos son muy distintos a los de la iglesia monasterial y semejantes a los de la parroquia de San Andrés de Anguiano en la que Solarte construyó, de 1545 a 1550, la capilla mayor, otras seis capillas y la sacristía ${ }^{10}$. Los dibujos de combados de las bóvedas del coro son prácticamente iguales a los de los dos primeros tramos de nave central concluidos en la iglesia de Anguiano.

Juan Pérez de Solarte que había trabajado como criado -posiblemente como aparejador $^{11}$ y en cualquier caso como colaborador muy próximo- de Martínez de Mutio en el abovedamiento de la iglesia de San Millán, contrató la realiza-

6. ARCHV, R. Ejecutorias, C.979.20.

7. MOYA VALGAÑÓN, J. G., Arquitectura religiosa..., T. II, p. 113.

8. Tasó la obra de Irache junto con Martín de Larrarte, vecino de Tafalla, y Martín de Landerrain, vecino de Logroño, que intervino como tercer tasador; IBARRA, J., Historia del Monasterio y de la Universidad literaria de Irache. Pamplona 1939, p. 116; PELLEJERO SOTERAS, C., "El claustro de Irache", Príncipe de Viana 5 (1941), pp. 18-19.

9. El coro se ha adjudicado a Juan Martínez de Mutio y la talla se ha relacionado con los artífices de la portada y coro de Briones -concluido en 1555-, y se ha sugerido, con acierto, la intervención de escultores del taller de Santo Domingo de la Calzada; MOYA VALGAÑÓN, J. G., Arquitectura religiosa..., T. I, p. 98; MOYA VALGAÑÓN, J. G., "La iglesia de San Millán...", p. 88; ARRÚE UGARTE, B., "El sistema hallenkirchen...", p. 135; ARRÚE UGARTE, B. y REINARES FERNÁNDEZ, O., "Construcción, ruina...", p. 88; MOYA VALGAÑÓN, J. G., Arquitectura..., pp. 172, 175 y 180. Ciertamente Martínez de Mutio cobró las rentas de Badarán hasta 1545 o 1546, según se declara en los pleitos de San Millán, mientras que el contrato de 1538 había previsto que las recibiera hasta 1542 , de modo que es muy probable que dirigiera otras obras en el monasterio y singularmente el coro alto, pero pensamos que, en la práctica, las ejecutó Pérez de Solarte. A Solarte enviaron como tasador a Irache y a él recurrieron en 1549 para el claustro.

10. ARCHV, Pl. Civiles, Quevedo (F), C.733.3. Concertó la obra el 24 de noviembre de 1544 con su cuñado Martín Ibáñez de Mutio como fiador. El 21 de noviembre de 1550 Rodrigo de Ezquerra, propuesto por la iglesia, y Juan de Acha, Ilamado por Pérez de Solarte, tasaron la sacristía y las siete capillas cerradas. Valoraron lo realizado en 1.744 .556 maravedís. Las tres capillas restantes se cerraron más tarde, pues hubo pleito y tardanza en el pago de las capillas.

11. Sobre los criados y las acepciones del término, BARRÓN GARCíA, A. A., "Primeras obras en La Rioja del arquitecto Juan de Rasines, 1469-1542", BMICA 110 (2012), pp. 12-14. 
ción del claustro conforme a un plan diseñado por el arquitecto burgalés Juan de Vallejo ${ }^{12}$. Éste presentó, además, un pliego con la valoración de lo que costaría realizar la panda que delimita con la iglesia: 1.083 .603 maravedís, es decir, casi 3000 ducados -2889 exactamente- que multiplicados por el valor de las cuatro pandas alcanza los 12.000 ducados en que se valoró el claustro. La relación de Vallejo, que es muy minuciosa, tenía previsto que cada capilla se cerrara únicamente con cinco claves y cuatro combados. Los maineles de las ventanas se describieron como pies derechos con sus basas y capiteles, y también se habló de pilares en la obra, pero nunca de columnas de modo que todo apunta a que se había previsto seguir un orden romano sencillo: el orden toscano, aunque el condicionado que finalmente suscribió Solarte incorporó elementos decorativos propios de otros órdenes. Además, significamos que Vallejo no hizo ninguna mención a la realización de una portada monumental que, de estar prevista, había de ir en la panda que tan cuidadosamente detalló. Por ello, se puede descartar que Vallejo proyectase la hermosa puerta de la iglesia, al menos en este primer momento. Al contrario, en la medición del muro se señaló la existencia de una puerta de acceso al templo que pensarían respetar (Fig. 1).

El contrato se firmó el 18 de febrero de 1549 ante Sancho de Olaso, escribano del valle de San Millán. Por el monasterio actuaron fray Pedro de Arenzana, abad, y el prior fray Lope de Salazar ${ }^{13}$.

En el articulado se contempló que Juan Pérez de Solarte hiciera las cuatro pandas del claustro conforme a dos trazas que se habían dado. Uno de los dibujos era la planta -la "plantaforma" - con "la manera que han de Ilevar las dichas claostras" y la otra, un alzado del patio: "el paño de fuera hazia el patio". La altura alcanzaría treinta pies que se habían de medir desde el nivel del suelo del cuerpo de la iglesia y llegaría "fasta la altura del corredor alto que ha de aver".

Se estableció que cada panda tuviera 144 pies de largo, poco más o menos, pero concretamente se señaló que la distancia fuera desde una responsión dis-

12. La autoría de Vallejo no se señala expresamente en el contrato pero se afirma varias veces en la documentación recogida en los pleitos habidos entre el monasterio y Pérez de Solarte. En 1559 Juan Pérez de Solarte lo menciona en la apertura de uno de los pleitos: "Juan de Vallejo maestro cantero que taso las dichas calostras e dio traça para ellas"; de nuevo lo recordó en enero de 1560 cuando Solarte reclamó al monasterio que nombrara tasador para valorar las mejoras realizadas en "las claostras del dicho monasterio fuera de la traza que dio para la dicha obra Juan de Ballejo, vecino de la ciudad de Burgos". Por su parte el cantero Juan de Lordieta dijo en sede judicial que el 17 de enero de 1555 el monasterio y el maestro cantero Pérez de Solarte concertaron que Juan de Vallejo, maestro cantero vecino de Burgos "que dio la traça de las claostras del dicho monasterio e hizo la yguala dellas fuese a ver e viese si la dicha obra yba conforme a la traça que el dio o si llebaba algunas faltas o defectos"; ARCHV, Pl. Civiles, Moreno (F), C.807.2.

13. Los datos que se ofrecen en adelante, salvo indicación contraria, proceden de los pliegos de un pleito entre el monasterio y el cantero: ARCHV, PI. Civiles, Moreno (F), C.807.2. 


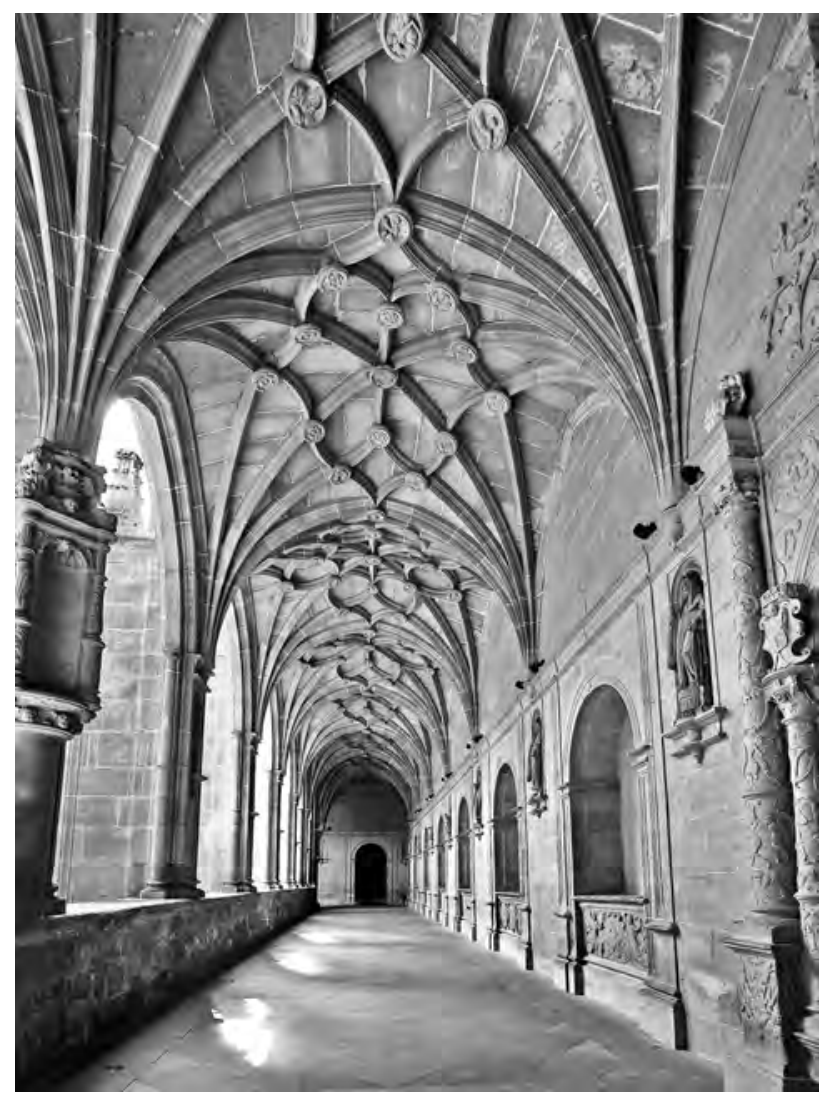

Figura 1. San Millán de la Cogolla. Panda norte del claustro.

puesta a la derecha de la puerta de acceso a la iglesia -se entiende que desde el claustro viejo y es la que hemos dicho que pensaron mantener- hasta otra colocada en la última capilla a los pies de la iglesia. Además se especificaba que a lo largo del espacio delimitado se construyera un muro sobre una zapata que ya existía fuera del vivo o borde de la pared de la iglesia. Para ello, con buena sillería de piedra de San Asensio, se dispondrían hiladas que ligaran la pared nueva con la vieja de modo que cada tres hiladas entrara una en el vivo de la vieja pared la distancia de un pie. En este paño, desarrollado a lo largo del muro de la iglesia, se debían abrir dos o tres arcos para sepulturas de siete pies y medio de ancho y una profundidad de dos pies y medio dentro del vivo de la pared. Estas sepulturas llevarían "gentiles molduras romanas" y pilares con basas y capiteles "con su alquitrabe e friso e cornisa que pasen por el trasdos del arco".

En cada paño se habían de disponer ocho capillas separadas por "represas gentiles" (ménsulas), adornadas con molduras romanas y tallas, y sobre éstas "an de nasçer sus jarjamentos muy vien hordenados". 
En el patio, los cimientos debían buscar suelo firme y alcanzar la profundidad del asiento de la iglesia con siete pies de tercio de vara de ancho y catorce pies de hondo, que fue la distancia calculada para llegar al suelo firme. Si había que ahondar más los cimientos se compensaría al maestro cantero conforme a la tasación del valor de la obra que estaba firmada por Juan de Vallejo. Por el contrario, si se alcanzaba la firmeza del suelo a menor distancia, se descontaría el valor según la citada valoración. Sobre estos cimientos había que levantar estribos o contrafuertes de dos pies y medio de ancho y cuatro de fondo y adornarlos con molduras -como también los antepechos de los huecos de las ventanas- "según que esta en la dicha traça". Los estribos del patio concluían con un remate "del romano" de unos seis pies de alto y, cerrados los arcos de las ventanas, corría un entablamento de una cuarta de vara de saledizo que discurría por todo el claustro a la altura del suelo del corredor alto.

Hechos los estribos, se cerrarían los cascos de las capillas conforme a la traza "e antes con bentaja que demynuyendo ansy en la graçia como en acresçentamiento de obra". Todas las claves debían Ilevar filateras labradas en la misma piedra con molduras romanas o follaje.

Seguramente en recuerdo de la obra del claustro de Nájera, se añadió que en las luces de las ventanas y encima de los antepechos se habían de disponer maineles y lazos "muy vien enbasados e capitelados segun como esta en la dicha traça".

Por el interior de las pandas, por encima de las represas, debía ir un arquitrabe, friso y cornisa de molduras romanas y "sy al maestro le paresçiere echar alguna talla o otra cosa se deja a su albedrio". Además, en cada cantón del claustro se debía disponer un encasamento "donde quepa una ystoria que su paternydad mandare, en el qual dicho encasamento aya su represa segun conbiene con sus gentiles molduras e talla del romano y en los lados sus pillaricos gentiles con muy buena hordenança con sus basas e capiteles y ençima su manera de tabernaculo de manera que el remate del dicho tabernaculo haga represa sobre que comiençar a nasçer los sarjamentos". Asimismo, debajo de cada una de las represas que marcaban el arranque de los jarjamentos había de disponerse otra represa curiosa - "elegida"- con un traspilar -con su basa y encapitelado- que contuviera un "encasamiento donde pueda estar una ymagen de tres pies e medio o quatro en alto como al maestro mejor le paresçiere, sobre esta a de venir un tabernaculo o benera acompañada de sus follajes del romano e otra talla como el maestro hordenare".

Juan Pérez de Solarte se obligó a abrir en los cuatro paños cuantas puertas fueran necesarias y le ordenaran. Asimismo había de dejar entrada y salida al "jardin e patio del dicho claostro".

La obra la debía dar concluida en ocho años por 12.000 ducados a cobrar de las rentas de Badarán -estimadas en mil ducados anuales- de 1548 hasta 1559. Para gestionarlas le proporcionaron una casa y bodega con sus beleces 
-"belezos"- y la casa del granero conocido como la Cabaña "para que en ellas pueda encubar y ençerrar pan y vino e rentas que se cogieren e venieren del dicho lugar de Vadaran durante los dichos doze años", así como "la casa que bybya Juan Martinez de Mutio"; es decir, con las mismas condiciones que Juan Martínez de Mutio había disfrutado mientras realizaba el abovedamiento de la iglesia. Correrían a cargo del maestro la realización de los andamios y la extracción y transporte de los materiales -piedra, cal arena y ripio.

Aunque la obra la realizó Solarte, es posible que la contratara en asociación con su cuñado Martín Ibáñez de Mutio, pues ambos canteros se obligaron a sacar en paz y a salvo a los fiadores.

Como en la documentación aportada por Juan de Vallejo para realizar y valorar la obra estaba previsto que el derribo del claustro viejo y sus paredes corriera a cargo del monasterio, se acordó que Juan de Vallejo estimara el precio de derrocar la vieja claustra y sus muros, así como la apertura de los cimientos de las nuevas paredes del claustro a realizar. El 4 de mayo de 1549 Vallejo, estando presente Hernando de Mimenza ${ }^{14}$, valoró el desescombro y apertura de cimientos en mil ducados que Solarte aceptó cobrar prolongando un año más la posesión de la renta de Badarán.

Las obras se ejecutaron a buen ritmo pues los muros perimetrales del claustro debían estar concluidos en 1554. Antes de la finalización de las obras hubo algunas discrepancias sobre el valor de las rentas de Badarán que se solventaron ante la Real Chancillería de Valladolid ${ }^{15}$ en abril de 1553: se había mejorado el rendimiento de uno de los molinos arrendados en Badarán con el añadido de una segunda rueda, pero el valor de compensación que Solarte debía aportar se había visto superado con la obra del granero de Altable (Burgos) y ciertas cantidades de cal que el cantero había entregado para otras obras en el monasterio.

Además, el 16 de abril de 1553, el prior de San Millán -fray Lope de Belorado- y los monjes se concertaron con Solarte para que hiciera ciertas mejoras no previstas en el contrato. Como las pandas del claustro habían de comunicar con la sala capitular, el refectorio, la librería y otras dependencias monásticas, era necesario disponer responsiones en los muros para facilitar el engarce de las futuras obras. Por ello acordaron con Pérez de Solarte que hiciera las respon-

14. Se conocen otras noticias de la intervención de Vallejo y Mimenza en obras del territorio riojano. En 1552 Vallejo informó al cabildo de la catedral de Santo Domingo sobre el estado y remedio de un pilar del respaldo del trascoro que estaba afectado y que finalmente reparó Juan Ochoa de Arranotegui; MOYA VALGAÑÓN, J. G., Documentos para la Historia del Arte del Archivo Catedral de Santo Domingo de la Calzada (1443-1563). Logroño 1986, p. 122. En mayo de 1553, junto con Hernando de Mimenza, contrató la construcción de la cabecera de la iglesia de Navarrete; MOYA VALGAÑÓN, J. G., Arquitectura religiosa..., T. II, pp. 122-126.

15. Aparte de la documentación principal del pleito de San Millán, ARCHV, R. Ejecutorias, C.851.41. 
siones en los muros de las dependencias anejas a pagar a tasación de oficiales una vez acabada la obra.

El 24 de julio de 1554, el abad y monjes de San Millán acudieron a la Real Chancillería de Valladolid e iniciaron una demanda contra Juan Pérez de Solarte pues alegaron que para hacer el claustro le habían cedido las rentas de Badarán durante doce años y habían acordado valorarlas en mil ducados anuales, pero que, en realidad, las rentas del lugar -rentas de pan y vino, molinos, censos, castillerías, martiniegas, pechos y derechos- suponían un valor superior a los mil ducados y que 12.000 ducados era mucho más de lo que merecían los claustros por lo que pedían que se tasaran las rentas en su justo valor y que simultáneamente se tasara la obra realizada en el claustro ${ }^{16}$.

El 12 de agosto de este año Juan Pérez de Solarte dio poder a su criado Martín de Zabala ${ }^{17}$ y a diversos procuradores para acudir a la Chancillería y reclamar que le pagaran lo realizado. Argumentaron que la obra valía 18.000 ducados y que las rentas de Badarán nunca alcanzaron los mil ducados anuales y que hubo años que no se pudieron arrendar por carecer de valor. Además, como habían transcurrido más de cuatro años desde la firma del contrato, defendieron que tenía plena vigencia, aunque se avenían a tasar la obra y a dar cuenta del verdadero valor de las rentas de Badarán.

El 22 de agosto de 1554, la Chancillería ordenó que se hicieran probanzas en el plazo de 80 días. Solarte pidió ante la justicia del valle en Baños de Río Tobía el 16 de septiembre -el alcalde mayor del Adelantamiento de Castilla en el partido de Burgos- que el abad presentara copia de las partidas del libro de visitas del monasterio que hablaran de las obras del claustro. Las visitas se aportaron al pleito y dan noticia del proceso constructivo, del avance de las obras y de las modificaciones pactadas entre las partes.

Así, el 11 de mayo de 1551, el visitador fray Diego de Badillo, abad de San Benito de Valladolid y general de la congregación, de común acuerdo con los monjes de San Millán, autorizó que en las obras se gastara un cuento al año y que para continuarlas se sacaran los cimientos de la claustra, de modo que se puede aventurar que hasta entonces únicamente se había intervenido en el muro que corre a lo largo de la iglesia y, como veremos, seguramente se estaba concluyendo el coro alto.

16. El monasterio perdió la demanda sobre el valor de las rentas de Badarán pues el 7 de agosto de 1555 la Chancillería impuso silencio al monasterio y absolvió a Juan Pérez de Solarte sobre el asunto de las rentas de Badarán, aunque ordenó que las partes cumplieran el contrato de febrero de 1549; ARCHV, R. Ejecutorias, C.851.41.

17. Juan Martínez de Mutio también menciona a Martín de Zabala como criado propio en el testamento que otorgó cerrado en febrero de 1558. Zabala tenía aposento y cajón con ropa en la casa-torre de Mutio en Aulestia; ARCHV, R. Ejecutorias, C.1027.32. La colaboración entre los canteros de la familia Mutio-Solarte y sus diversos oficiales sería muy frecuente. 
El 27 de mayo de 1552 los visitadores generales -fray Bartolomé de Nájera, abad de San Andrés de Espinareda (León), y fray Martín de Azpeitia- constataron que, a pesar del acuerdo del visitador anterior, no se gastaba en la obra más que la renta de Badarán. Determinaron que para las obras se añadieran las rentas de Camprovín y las del partido de la Bureba (Vallarta, Vallartilla, Valluércanes y Valdegovía) y que lo primero que se construyera fuera la panda del claustro que corresponde con la iglesia "para que se puedan servir del coro alto" y que también se hiciera la escalera que se ha de alzar junto a la puerta que comunicaba con la iglesia. De modo que el coro se habría acabado poco antes y, como hemos dicho, ha de ser obra de Solarte.

El 7 de marzo de 1554, el visitador fray Bartolomé de Alvear, abad de San Benito de Valladolid y general de la congregación, enterado de las deudas y de las escasas rentas recogidas el año anterior, ordenó que cesaran las obras por dos años y que se pagaran las deudas.

El 8 de noviembre de 1554, en el valle de San Millán, Martín de Zabala, criado de Solarte, presentó a varios testigos entre los que destacamos a Martín lbáñez de Mutio (ca. 1507) ${ }^{18}$, vecino de Guernica y morador en Azofra -donde realizaba la iglesia parroquial-, a Juan Martínez de Mutio (ca. 1519), maestro cantero vecino de Guernica, hermano de Juan Martínez de Mutio, a Hernando de Mimenza (ca. 1513), maestro cantero vecino de Guernica y estrecho colaborador de Juan de Vallejo, a Juan de Lejardi (ca. 1514), cantero vecino de San Andrés de Echabarría, y a Juan Ochoa de Arranotegui -o Arronategui- (ca. 1512), maestro cantero vecino de Santo Domingo de la Calzada.

Las preguntas del interrogatorio informan de la rapidez en la construcción. Pérez de Solarte defendía que lo realizado y lo que quedaba por acabar en cumplimiento del contrato valía más de 18.000 ducados sin contar las mejoras que le habían solicitado en 1553. Además, añadió que le habían encargado realizar cuatro arcos para sepulturas para trasladar ciertos bultos ${ }^{19}$ de tres altares del claustro viejo, construidos de nuevo en los cantones del claustro nuevo. Estas mejoras, junto con las de las claves y los nervios de las capillas y las responsiones para las edificaciones anejas, las valoraba en más de 1500 ducados. Defendía que, aparte de las modificaciones pactadas, la obra se había ejecutado conforme a lo contratado y que había empleado continuadamente a treinta oficiales y seis carreteros en la obra sin atender ninguna otra ${ }^{20}$.

18. Las cifras que se indican se deducen a partir de la edad que declaran en las testificaciones del pleito.

19. Yepes escribió que en estas sepulturas nuevas estaban enterrados señores de la casa de Haro o casa de Vizcaya "que en tiempos antiguos competía con los mismos reyes", de Mendoza y de Ábalos; YEPES, Fray A. de, Coronica General de la Orden de San Benito. Tomo I. Centuria I. En la Universidad de N. ․ S.

20. El abad Fray Gonzalo de San Millán declaró que Solarte llevaba otras obras como la iglesia de Santa María de Bobadilla, población cercana a San Millán. Algunos de estos oficia- 
El escribano Sancho de Olaso, ante el que había pasado el contrato, testificó que Juan Martínez de Mutio había administrado la renta de Badarán -durante cinco años según declaró Martín Ibáñez de Mutio- y después de él la tuvieron durante seis años ciertos vecinos de Badarán a condición de cederla a favor del maestro que contratara la obra de los claustros. Otros testigos naturales de Badarán certificaron que había habido algunos años de calamidades y escasas rentas por sequía, hielo, niebla, "argabisos" (por argaviesos) y aguaduchos. Juan de Lejardi declaró que trabajaba en el claustro desde el comienzo de su construcción y que vio venir a Juan de Vallejo a tasar la obra a realizar y, después, a valorar el desescombro del claustro viejo. Juan Martínez de Mutio expuso que había visto a su hermano homónimo cobrar las rentas de Badarán y que la obra del claustro "como maestro experimentado en el arte de la cantería" la valoraba en más de 18.000 ducados. El mismo valor señalaron Juan Ochoa de Arranotegui y Hernando de Mimenza quien declaró que estuvo presente en San Millán al hacerse el concierto del claustro y que vio las trazas y contrato. Además, había visto los cimientos abiertos porque, "como maestro abil y esperto que es en la arte de canteria", fue Ilamado para que los viese antes de que se pusiese la piedra.

En 1555 Solarte presentó nuevos testigos para probar sus argumentos: Cristóbal de Carotegui (ca. 1515), cantero vecino del valle de Léniz (Guipúzcoa) que había trabajado en la apertura de los cimientos y en el desescombro del claustro viejo; Juanes de Baquelua -o Huaquelua- (ca. 1520), cantero habitante en Villar de Torre que también había trabajado en la cimentación del claustro nuevo; Martín de Morga (ca. 1505) y Juan de Lordieta (ca. 1505) vecinos de San Millán que habían visto el claustro viejo y habían participado en la cimentación de la nueva obra. Como era de esperar, todos los testigos presentados por Solarte corroboraron que el valor del claustro superaba 18.000 ducados, que en el desescombro del claustro viejo y la apertura de cimientos se gastaron más de los 1000 ducados tasados por Vallejo, que, además, Solarte había realizado las mejoras en las responsiones de los muros que le habían pedido, mejoras en las capillas, cuatro sepulturas y tres altares en los tres cantones del claustro; innovaciones solicitadas por el monasterio que suponían más de 1500 ducados. Para negar algunas dudas presentadas por el monasterio se incorporaron nuevas preguntas al interrogatorio que trataban de establecer si la longitud de la panda del claustro que delimitaba con la iglesia alcanzaba 144 pies. Los testigos declararon que la longitud, medida por los muros interiores era de 136 pies

les serían Juan de Amarista, Martín de Zabala y Martín de Baquedano, criados de Juan Pérez de Solarte que testificaron en 1551 en el valle de San Millán en un acto de requerimiento que el cabildo y concejo de Anguiano hicieron a Juan Pérez de Solarte y María Ibáñez de Mutio; ARCHV, Pl. Civiles, Quevedo (F), C.733.3 También Juanes de Baquelua (ca. 1520) que cobró y firmó diversos recibís en nombre de Solarte por la obra de Anguiano en la que trabajó seis años y Sebastián de Aulestia (ca. 1522) que laboró cuatro años en Anguiano. 
pero que añadido el grosor de los muros, que según ellos correspondía a la posición de las responsiones señaladas en el contrato, se obtenían 146 o 147 pies.

Juan de Lordieta recordó que el 17 de enero de 1555 el prior del monasterio -fray Diego de Montoya- y el maestro cantero de la obra habían acordado que Juan de Vallejo "que dio la traça de las claostras del dicho monasterio e hizo la yguala dellas fuese a ver e viese si la dicha obra yba conforme a la traça que el dio o si llebaba algunas faltas o defetos" y que, después de vista, si el prior lo deseaba, se tasase la obra realizada y también lo que habían podido valer los frutos de Badarán. También acordaron hacer cambios en el claustro con tal de que, acabada la obra, se tasase y el valor declarado se le pagase a Juan Pérez de Solarte de las rentas de Badarán ${ }^{21}$.

El maestro cantero Pedro de Rasines (ca. 1505-1572), vecino de Rasines, declaró que había visto cerradas dos capillas en el claustro con 17 claves con sus combados, talla y medallas adecuadas y que, sin embargo, la traza que Solarte le había enseñado mostraba capillas diferentes y de menor labor. Otro tanto refrendaron el resto de los testigos: que en el proyecto original, salvo las capillas de los cantones -que estaban delineadas con mayor número de claves- se dibujaban capillas de cinco claves y que, en su lugar, las dos capillas ya acabadas eran de 17 claves - una con 24 combados y otra con 32- por lo que "estan mejoradas en hermosura y costa y gentileza" que se estima en 18.000 maravedís por cada capiIla. Las dos capillas señaladas se corresponden con las que se ubican en el centro del tramo norte, delante de las sepulturas más destacadas (Fig. 2).

La Chancillería sentenció, el 7 de julio de 1555, que las partes habían probado sus propósitos y ordenó que cumplieran la escritura de contrato de 1549. Las diferencias que mantenían sobre el valor de la obra y la ejecución del contrato no parecían irreconciliables. Todo lo contrario, se habían hecho cambios para enriquecer la obra -por ejemplo el aumento del número de claves en las bóvedas- y seguramente habían sido comentados y consensuados entre las partes. Por ello, el 2 de marzo de 1556 el prior -fray Diego de Montoya- y los monjes se concertaron con Pérez de Solarte nuevamente antes de cerrar las capillas. Señalaron que si se hacían conforme al contrato y traza de 1549 quedarían "pobres de combados y claves segun la obra es". Para remediarlo acordaron con Solarte que en los

21. En enero de 1560, Solarte denunció que el convento también había hecho venir, en agosto de 1555 y sin su conocimiento, a Pedro de Rasines y Rodrigo Ezquerra para que tasasen la obra y declarasen los defectos que pudieran existir. Solarte protestó que hubieran visto la obra sin estar él presente y sin enseñarles la traza "hecha por el maestro Vallejo" por lo que pidió que se llamara a Vallejo para que, conforme a lo acordado, declarara las faltas, si las hubiera, y viera las mejoras realizadas a ruego del convento "pues es persona esperta en el arte de jumetria y persona que tiene entendida la dicha obra y calidades como trazador que fue traido para hello por el dicho monasterio". Poco después, Juan de Vallejo vino a visitar la obra en compañía de Hernando de Mimenza. 


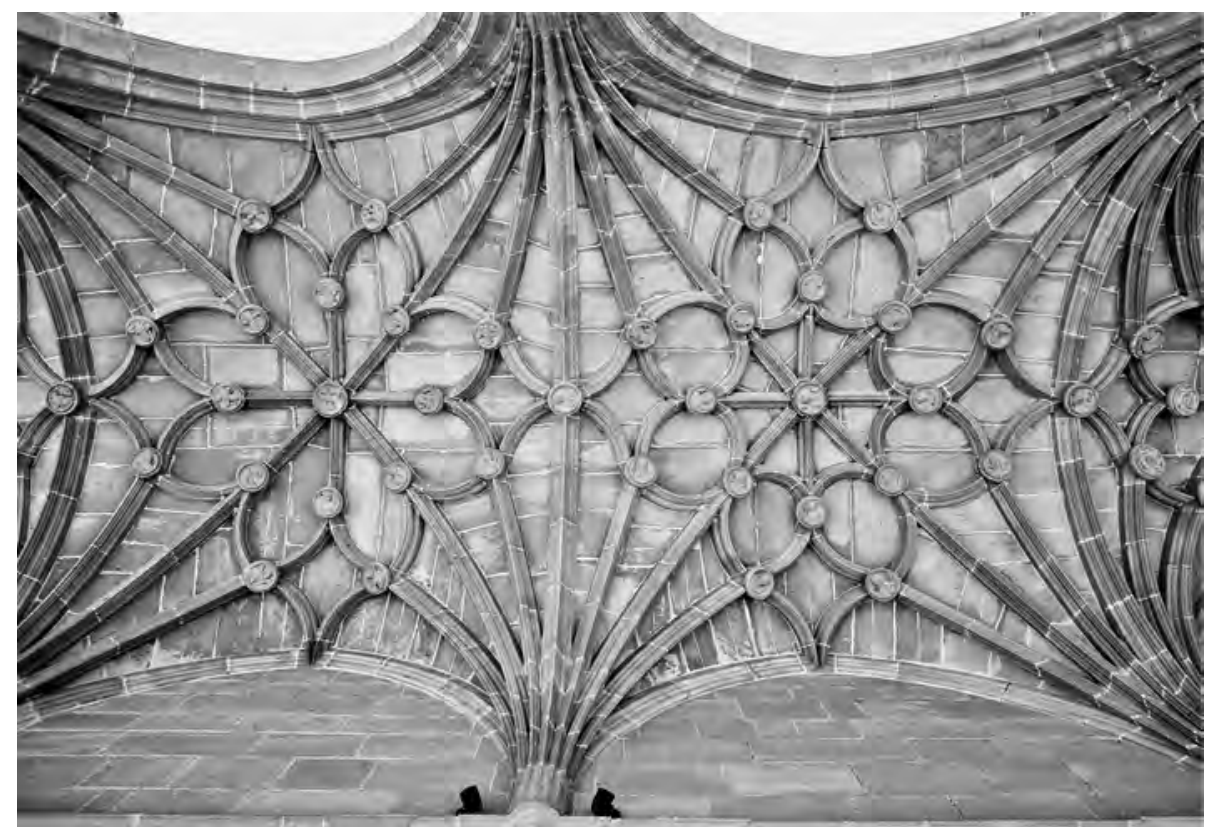

Figura 2. San Millán de la Cogolla. Bóvedas de 17 claves con 24 y 32 combados, 1553.

cuatro cantones del claustro las capillas Ilevaran 17 claves con sus combados y pies de gallo; en las capillas de la panda que daba a la iglesia, 13 claves cada capilla con sus combados y pies de gallo; en la panda del claustro paralela al capítulo, 11 claves con sus combados y pies de gallo en cada capilla; y en las otras dos pandas, que una llevara en cada capilla 11 claves -el tramo del refectorio- y la otra 9 claves con sus combados y pies de gallo. Además, todas las claves de las capillas de las cuatro pandas habían de mostrar florones -"floretones"bien obrados por buen maestro y a contento del prelado del monasterio. Por último reconocieron que lo realizado y lo innovado por Juan Pérez de Solarte más allá de lo concertado en el contrato "e traza primera e tasaçion que hiço Juan de Ballejo" había sido por mandato del convento y en utilidad y provecho de la obra, por lo que se debía pagar después de tasar la obra personas nombradas por las partes y, si no se concertaban, por un tercero.

Todavía el 5 de octubre de 1556 las partes volvieron a modificar el contrato pues acordaron que, en lugar de los floretones que el cantero había de labrar en las claves, se pusiesen medallas e imágenes de santos, por lo que le pidieron a Solarte que en todas las claves que se hiciesen en adelante se tallaran "imágenes o medallas muy bien obradas e abultadas e de buena mano por manera que las dichas claostras sean mas luzidas e autoriçadas e que todo lo que en ello hiziere e pusiere se le pagara conforme al contrato". Se tallaron florones en las claves 
secundarias de las bóvedas intermedias de la panda norte, en la bóveda del rincón que comunica con el salón de los Reyes - con San Juan Bautista en el centroy en la siguiente capilla del tramo oeste, cerradas, por tanto, con anterioridad. El resto de las claves de los lados oeste, sur y este muestran medallas con figuras. Además, las capillas de la panda sur, que limitaba con el refectorio, finalmente se cerraron con bóvedas de 13 claves, en lugar de las once señaladas en el contrato de julio de 1555. En las capillas de los lados este y oeste, Solarte se atuvo a lo concertado. La desigual densidad de claves en los tramos remarca la distinta jerarquía en los tramos del claustro.

El 29 de abril de 1559 Juan Pérez de Solarte, acabada la obra, pidió a fray Pedro de Arenzana, prior del monasterio, el abono de los más de 6000 ducados que se le debían, pues ya había anunciado que la obra merecería 18.000 ducados en lugar de los 12.000 establecidos en el concierto. El monasterio alegó que no había cumplido con el plazo de 8 años para ultimar las obras y que aún no había concluido de obrar lo contratado. Solarte indicó que tenía la obra acabada y que estaba dispuesto a corregir lo que le especificaran, por lo que pedía que se nombrasen tasadores. Añadió que no había acabado en el plazo ajustado porque le habían encargado que siguiera una nueva traza con más obra que la especificada en el primer contrato y porque le habían entretenido dos años en pleitos. El representante del monasterio no se avino con el cantero y señaló, aparte de otros argumentos jurídicos que buscaban dilatar la causa, que no se habían realizado los maineles y lazos de las ventanas del claustro previstos en el primer contrato de 1549.

La Chancillería determinó, el 12 de diciembre de 1559, que las partes cumplieran los contratos firmados y que nombraran tasadores que valoraran lo realizado. Como el monasterio se negaba a nombrar tasadores, el maestro cantero pidió carta ejecutoria a la Real Chancillería y con ella reclamó al monasterio, en enero de 1560, que nombrara tasador. Él trajo a Juan Ochoa de Arranotegui para esta labor y, finalmente, el abad -fray Juan de Cañas- presentó, el 14 de enero, a Juan de Vallejo para que actuara como su tasador pero, como no se concertó con el propuesto por Solarte, las partes acordaron que mediara como tercer árbitro Martín de Ibargüen o Ibarguren -Martín de Miranda-, vecino de Miranda de Ebro. De parte de Solarte se presentaron a los tasadores las escrituras y dos trazas en pergamino que el maestro de las obras poseía: una de la planta del claustro correspondiente al contrato de 1549 y otra firmada por fray Rodrigo de Badillo, general de la congregación benedictina que había visitado el convento en 1551. En el reverso de este segundo proyecto se señalaba cómo había ordenado el padre general que se siguiese ese segundo dibujo. Vallejo y el monasterio protestaron que no se había presentado la segunda traza del contrato de 1549: el alzado del patio que se describe como "la montea de los estribos y ventanas y laços y maineles".

Por su parte, el monasterio mostró a los árbitros un memorial de faltas que probablemente se había redactado a partir de los informes de Juan de Vallejo, Pedro de Rasines y Rodrigo Ezquerra en agosto de 1555. Se denunciaba que no se ha- 
bían labrado los maineles y los lazos que debían ir en las ventanas del patio -mengua que cifraban en más de 800 ducados- . Encontraban que los seis escarzanos abiertos en el claustro eran tan bajos que no se podían colocar puertas; que los encasamentos de las imágenes de todo el claustro y su adorno de peanas, tabernáculos, veneras y talla era "tan apocado y falto que no se sufre quedar en obra semejante", además de no haberse realizado los traspilares que se expresaban en el contrato. Denunciaban que los antepechos y los estribos exteriores del claustro no tenían la altura necesaria y que eran "feos y bajos que aun el remate o candelero de ello no llega ni sube a igualar con el entablamento del claostro", y, además, no tenían "gentiles remates del romano sino muy broznos y bastos". También afearon la delgadez de los pilares de los rincones y la desigualdad de altura en las columnas de los pilares. Sobre la portada que comunica con la iglesia opinaron que "la talla o romano de la puerta de la iglesia y todo lo de aqueIla portada esta poco levantado [de escaso relieve] y es todo apocado y mal labrado y no como conviene para semejante puerta". Tampoco apreciaron las filateras de las capillas "que son muy pequeñas y asi los floretones o medallas son tan pequeñas y menudas que no salen ni se ven". Lo mismo consideraron del "friso o letrero que cerca toda la claustra es muy estrecho demasiadamente que no es para se poner letrero en $\mathrm{el}^{\prime \prime}$. Incluso pusieron en entredicho si la pared que limita con la iglesia se había construido como se indicaba y si los cimientos tenían la profundidad señalada. Hoy se sabe que el muro se ejecutó como se ordenaba en el contrato, pues está separado de un hueco existente entre el muro de la iglesia y el claustro que se ha encontrado recientemente: en 1999 se descubrieron dos pequeñas puertas en el espacio que delimita la iglesia con el claustro ${ }^{22}$.

Además, el representante del monasterio se quejó de que Solarte no presentara una de las trazas del contrato de 1549 y que sin ella Juan de Vallejo no estaba dispuesto a tasar. Pérez de Solarte declaró que no tenía más planos y pidió que el monasterio presentara los que poseyera -aunque, a menos que la traza realmente estuviera desaparecida, tenía que saber que no la podían mostrar porque se la habían entregado a él en el acto de contratación-. Además, aseguró haber realizado la obra conforme a la traza y contrato y haber ejecutado cambios y mejoras -estimadas en más de 5000 ducados- con consentimiento y a petición del convento y del padre general de la orden -Rodrigo de Badillo-, así en las claves y combados de las capillas, en los arcos perpiaños, en los antepechos, basas y molduras, en las sepulturas, en la puerta principal y en el resto de las puertas del claustro. El cantero respondió con otro extenso memorial en el que negó los defectos alegados por el monasterio y en el que pidió que los maineles y los lazos de las ventanas se valoraran por la tasación de Vallejo y Mimenza de 1555 para

22. REINARES FERNÁNDEZ, O., "La iglesia del monasterio de San Millán de la Cogolla de Yuso en el siglo XVII", El pintor fray Juan Rizzi (1600-1681): las órdenes religiosas y el arte en La Rioja. Logroño 2000, pp. 232-234; MOYA VALGAÑÓN, J. G., "La iglesia de San Millán...", p. 89. 
que se le rebatiera la suma que se hallara. Dijo que los escarzanos de las puertas secundarias del claustro eran correctos y en correspondencia con los de la puerta principal; que los pilares de los rincones podían soportar el doble de la carga recibida y que los habían aprobado Vallejo y Mimenza; que los encasamentos de las imágenes eran superiores a los de la traza "para que las imágenes digan mejor dentro en su encasamento" y varias veces se refirió a que las claves y los remates de los contrafuertes del patio los había labrado "el oficial que a sus reverencias contento", que la talla de la portada de la iglesia ni siquiera se le había tasado por haberla hecho "el oficial de quien mas se fiaban sus reverencias", lo mismo que las 380 claves de las bóvedas por "haberlas labrado el imaginario de quien sus reverencias estaban y estan muy satisfechos pues veian como las hacia y se contentaban en verlas hacer de cerca y ahora por estar altas si no alcanza la vista que no sea a mi culpa y se tenga en cuenta el requerimiento que le hicieron para que todas las hiciera tan pequeñas". Aparte dijo que había añadido mascarones en el entablamento del claustro, y que en el corredor alto, situado sobre el claustro, había dispuesto en el suelo sillares en una superficie de seis pies de ancho y había levantado dos pies de pared por todo el perímetro del claustro.

El 26 de enero de 1560 se juntaron los tres tasadores a la vista de los contratos y planos presentados -Vallejo señaló que en ausencia de la montea de los estribos y ventanas-. Los tasadores de las partes no se pusieron de acuerdo y Martín de Ibargüen les solicitó que presentaran tasaciones separadas para que posteriormente pudiera juzgar y mediar. Vallejo declaró que se debían realizar los maineles y los lazos de las ventanas del claustro y, además, descontársele 172.338 maravedís, fundamentalmente porque cada lado del claustro medía por dentro 136 pies en lugar de 144 y esto suponía un ahorro en paredes, molduras, cimientos... Los tres tasadores estuvieron de acuerdo en valorar en 459.835 maravedís ciertas mejoras como tres arcos para sepulturas y tres arcos para altares que había abierto en los paños de las paredes (94.218 maravedís), también 194 claves de bóvedas (139.940 maravedís), 200 piezas de combados (79.200 maravedís), la mejoría en la obra de la portada (41.646 maravedís) y las responsiones y los jarjamentos de los muros que daban a las dependencias anexas que se habían de construir.

Tres días después, Juan de Vallejo retiró su declaración, pues alegó que por ponerse de acuerdo con los otros dos tasadores había tasado la obra por encima de su valor, en perjuicio del monasterio. Sin embargo, los otros dos tasadores se reafirmaron en las mejoras de las claves, combados, sepulturas... y tasaron que valían 504.389 maravedís ${ }^{23}$.

23. Hicieron esta nueva tasación el 30 de enero de 1560. Por maese Martín firmó su criado Miguel de Aguirre. 
Por su parte, Juan Ochoa de Arranotegui hizo un informe más favorable a Solarte que suponía, aparte de las mejoras pactadas por los tres tasadores, otros 364.712 maravedís a favor del maestro de las obras. Consideró que el contrato indicaba que el muro fuera de responsión a responsión y que había 146 pies largos. Además, refrendó que en lugar de tres arcos para sepulturas había seis y, por tanto, tres de ellos eran de mejora como también lo eran las 196 claves, los 200 combados y los cruceros dispuestos en seis capillas que dan a la iglesia pues en el proyecto no estaban señalados. Sugirió que para resolver el asunto de los maineles y los lazos, como la traza original no aparecía y nada se podía certificar sin ella, Juan de Vallejo realizara bajo juramento otra conforme a la que había hecho para el contrato del claustro. Declaró que, según le habían informado, los

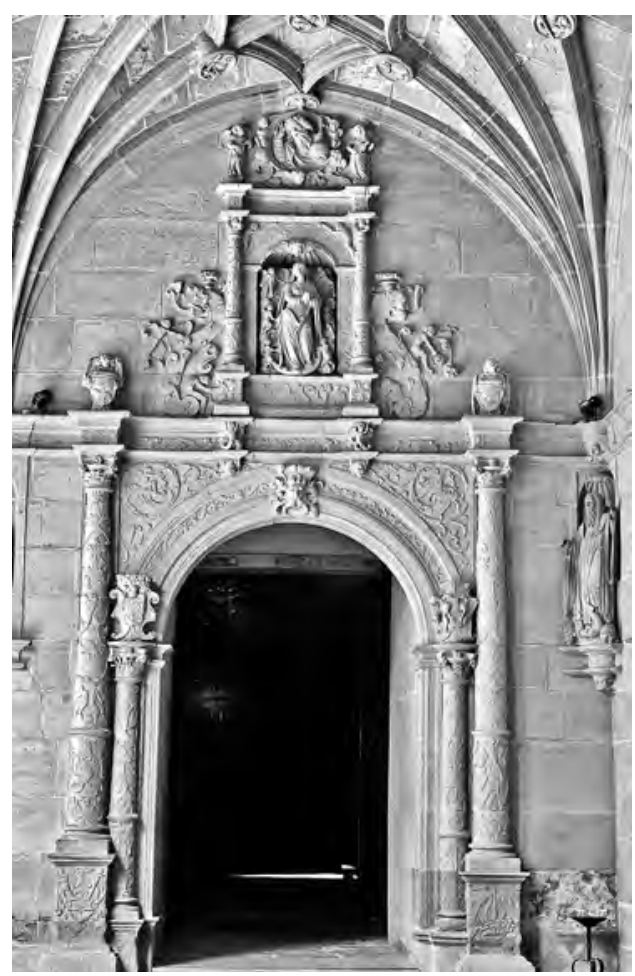

Figura 3. San Millán de la Cogolla. Portada, 1554. escarzanos de las puertas se hicieron conforme al de la entrada de la iglesia y que se siguió el parecer de fray Juan Pardo, abad de San Juan de Burgos, y de Juan de Villarreal, imaginero, que vinieron a dar el segundo plano presentado.

El 4 de febrero el monasterio apeló contra las tasaciones y sostuvo que para encontrar la segunda traza con la montea de las ventanas que tanto lo beneficiaría había realizado todo tipo de diligencias pero que no aparecía porque había de tenerla -y así lo afirmaban los frailes-, Pérez de Solarte como poseía las otras dos: la planta primera y la que hicieron fray Juan Pardo y Villarreal sobre los cuartos, aposentos y oficinas de toda la casa. Indicaron que el perjuicio de no realizar los maineles y los lazos suponía más de 700 u 800 ducados. Por otra parte indicaban que "cargar las capillas de tantas clabes y conbados no es haçerlas mas fuertes sino mas flacas e mas peligrosas y menos duraderas y en tan pequeño campo y hespaçio con ellas haçerlas feas y menos bistosas". Y por último negaron que hubiera mejora en la puerta de la iglesia pues Solarte se había obligado a realizarla por su cuenta y la obra estaba indicada en la traza del abad de San Juan de Burgos y de Villarreal (Fig. 3). Noticia interesante que confirma que el proyecto de Vallejo para el claustro se adaptó al gusto de la Orden -ya hemos 
destacado el parecido con el monasterio de Irache- y que en el diseño de la portada intervino Juan de Villarreal y no Vallejo, contra lo que se ha supuesto.

La Chancillería sentenció, el 5 de julio de 1560, que las partes presentaran testigos y que probaran sus alegaciones y el 9 de agosto revocó las tres tasaciones realizadas y señalaron que, acabada la obra según el contrato de 1549, Pérez de Solarte pudiera seguir juicio para reclamar las mejoras realizadas. Además, pidieron a las partes que juraran si estaba en su poder la traza que no se había presentado.

Como el dibujo seguía sin aflorar y las mejoras suponían más de 4000 ducados y los maineles y los lazos se podrían hacer -de aparecer el proyecto- por unos 500 ducados, Solarte solicitó provisión real para obligar al monasterio a que tres monjes juraran sobre la posesión de la traza. El 2 de diciembre de 1560 llevó la provisión al alcalde del valle de San Millán que la leyó a las puertas del monasterio. Fray Juan de Cañas, abad, juró que "nunca vio la traça de las claravoyas contenida en la dicha provision ni la tiene en su poder ni sabe que este en el dicho monasterio ni quien la tenga". Lo mismo juraron otros dos frailes. Fray Jerónimo de Manjarrés añadió que "el monasterio avia echo diligençias en buscar la dicha traça e no la podiendo allar avia echo leer çensuras y escomuniones publicamente en la iglesia del dicho monasterio e ninguna persona la avia manifestado". Fray Blas de San Millán recordó que, unos seis años atrás, el abad -fray Gonzalo de San Millán- había solicitado a Pérez de Solarte que mostrase las trazas y que, al decir de algunos, entre las dos o tres que había llevado, estaba la del alzado del patio, pero que el maestro se las volvió a llevar y que no sabía determinadamente si entre ellas estaba la que se buscaba. Poco después, el 18 de enero de 1561 Solarte juró que no poseía más planos.

La Chancillería publicó sentencia en grado de revista el 5 de marzo de $1561^{24}$. Confirmaron la sentencia anterior pero ordenaron que las partes nombrasen tasadores y en discordia la justicia un tercero que declarase lo que faltaba por realizar en la obra principal conforme al contrato y trazas de 1549 y que se tasasen las mejorías hechas en la obra. Condenaron a Solarte a que inmediatamente comenzara a realizar lo que los tasadores determinaran que faltaba por acabar y mandaron que el monasterio, al concluir esta obra, pagase al cantero lo que montasen las mejorías.

El desacuerdo de las partes hizo que el cantero acudiera para ejecutar la sentencia a la justicia del valle -el licenciado Jáuregui alcalde mayor del Adelantamiento en Baños de Río Tobía que era la justicia más cercana y la que, en principio, correspondía- y que el monasterio fuera al corregidor de Santo Domin-

24. Aparte de la documentación aportada por el pliego del pleito; ARCHV, R. Ejecutorias C.999.30. 
go de la Calzada porque desconfiaba del alcalde del valle, ya que los vecinos mantenían muchos pleitos y diferencias con el monasterio.

En septiembre de 1561 Solarte nombró como tasador a maestre Domingo de Asteasu, vecino de Laguardia, y el convento a Juan de Vallejo pues dijeron que tenía la traza que Ilamaban montea. Al no acudir Vallejo, el alcalde del valle de San Millán nombró a Martín de Arteaga, cantero vecino de Belorado, que fue rechazado por el monasterio y en su lugar presentó a Pedro de Castañeda, cantero de Burgos que había sido propuesto por Vallejo. Simultáneamente, el monasterio apeló a la Chancillería y solicitó que el alcalde del Adelantamiento no acogiera la causa, pues pendía ante el corregidor de Santo Domingo de la Calzada.

Como Pedro de Castañeda no acudió a Baños de Río Tobía, el 3 de noviembre de 1561 el alcalde del Adelantamiento nombró como tasador a Martín de Aguirre, cantero residente en Cabredo (Navarra) ${ }^{25}$. Por el contrario, como el tasador de Solarte no asistió a la demanda presentada en Santo Domingo de la Calzada, el corregidor nombró como tasador a Juan de Henestosa. Los cuatro tasadores, negando las partes a los terceros nombrados por el alcalde y el corregidor, fueron al monasterio y tasaron la obra a la vista de los contratos y de los planos. En esta ocasión el monasterio presentó un dibujo nuevo con la montea del alzado del patio, pero Martín de Aguirre señaló que no estaba firmada mientras que la que se había presentado en 1549 constaba en la escritura de contrató que la habían suscrito las partes contratantes y el escribano Sancho de Olaso. Aguirre valoró las mejoras en 1.284.998 maravedís -casi 3500 ducadosa lo que había que descontar el valor de los maineles y los lazos no realizados ${ }^{26}$. Lo mismo declaró Domingo de Asteasu que no pudo concertarse con Pedro de Castañeda. A la vista de ambas tasaciones el alcalde del Adelantamiento, el 10 de noviembre, ordenó que se pagara a Pérez de Solarte y éste se mostró dispuesto a realizar los maineles y los lazos si el abad y convento así lo deseaban y si le daban traza de los lazos y maineles "de maestro sabyo qual convenga a la dicha obra". Además, suplicó al alcalde que proveyera para que el abad y convento le entregaran el diseño y le permitieran entrar y salir libremente en el claustro y acceder a las canteras, carriles y pastos como estaban obligados conforme al contrato. Tres días después un procurador del monasterio señaló al alcalde que el pleito pendía ante el corregidor de Santo Domingo y en la Chancillería y que el tercer tasador no podía haber actuado porque, en realidad, no se habían reunido los tasadores de las partes y, por tanto, no constaba discordia entre ellos. A pesar de esto, el alcalde hizo trasladar al monasterio la petición de Solarte y el cumplimiento de lo que él había acordado bajo pena de 30.000

25. En adelante los datos que se ofrecen proceden, salvo que se indique lo contrario, de los pliegos de un pleito distinto: ARCHV, PI. Civiles Moreno (F) C.1257.5.

26. Por no saber firmar, la declaración está suscrita por su hijo Juan de Aguirre. 
maravedís. Juan de Solarte, hijo del maestro, Ilevó la petición al monasterio que no la atendió. Los monjes alegaron que la causa se veía ante el corregidor de Santo Domingo que había nombrado como tercero a Juan de Henestosa quien, junto con Pedro de Castañeda, había estado durante más de veinte días en el claustro, mientras que los otros tasadores habían resuelto "tan apasyonadamente en el negoçio que no hestobyeron un quarto de hora en el dicho monasterio para ver la dicha obra", siendo asunto de tan gran calidad y cantidad y "çegados de su pasyon hiçieron grande exorbitançia y exçeso".

El alcalde no complació al procurador del monasterio y ordenó que se embargaran bienes del monasterio hasta cubrir la deuda de los aproximadamente 3500 ducados en que se habían tasado las mejoras realizadas por Solarte. Efectivamente, entre el 25 y el 27 de noviembre se ejecutaron diversos bienes del monasterio en Tricio, Badarán, Nájera, Cárdenas y Camprovín, pero el monasterio consiguió en la Chancillería, el 27 de enero de 1562, que se revocaran las sentencias del alcalde, que le devolvieran los bienes y que se condenara en costas al licenciado Jáuregui, alcalde del Adelantamiento de Castilla, y que, además, retornara la causa al estado anterior a la intervención del alcal$\mathrm{de}^{27}$. Los jueces de Valladolid también acordaron que las partes presentaran los planos y que nombraran de nuevo tasadores, con reserva para sí del nombramiento de tercero. El 31 de enero Pérez de Solarte presentó en la Chancillería dos trazas: una firmada por él, por el abad Pedro de Arenzana y por el escribano Sancho de Olaso, era la que se presentó en el contrato de 1549; otra estaba firmada en la vuelta por fray Rodrigo de Badillo, general de la orden, y era la planta de los cuartos circundantes al claustro, y en virtud de esta planta se había ordenado que se hiciesen las mejoras. También presentó una tercera traza, más pequeña que las otras dos, que era la que había llevado la parte del monasterio ante la justicia del valle de San Millán y estaba firmada por el licenciado Prado, teniente de corregidor de Burgos y por el escribano Francisco de la Piedra. Este tercer proyecto mostraba claraboyas, antepechos, corredores y sobreclaustro. Pérez de Solarte juró no tener más dibujos del claustro "pero que en quanto toca a otros edificios fuera de la dicha claustra este que declara dio al monasterio çiertas trazas e las tiene el monasterio en su poder que no tocan a este negoçio" sin que sepamos si se refiere a dependencias anexas al claustro o al coro alto de la iglesia que por el estilo se le puede adjudicar y que hemos visto que estaba realizado o casi concluido en 1551.

A Valladolid acudieron fray Blas de San Román, que confirmó que la tercera traza la había presentado el monasterio ante el alcalde del valle de San Millán y que se correspondía con "la montea que Juan de Vallejo esibio ante el corregidor de Burgos por provision de su majestad", y Pedro Martínez de Azofra, cléri-

27. ARCHV, R. Ejecutorias, C.1019.5. 
go, que aportó que "la montea que Juan de Vallejo exybio ante el corregidor de Burgos es... los pasamanos e lazos e mayneles la qual es al tanto de otra que dizia el dicho Vallejo que le dieron al tiempo que tomo a facer la dicha obra".

El 13 de febrero se juntaron dos nuevos tasadores -Juan Martínez de Cortabitarte, nombrado por Solarte, y Juan de Escalante, cantero de Valladolid nombrado por el monasterio- y en su tasación revelaron que la tercera traza o montea no podía corresponder con la presentada en 1549 por exhibir adorno "moderno" en los remates de los estribos en lugar de "romano", porque en el contrato se había señalado que fueran de seis pies y en el dibujo, al menos, alcanzaban dieciocho pies, por tener distinto tamaño las ventanas, y por contener tres maineles cuando en la plantaforma de 1549 se habían dibujado dos ${ }^{28}$. La Chancillería, a la vista de estos pareceres, falló que Solarte acabara la obra conforme a las trazas y después pudiera reclamar lo que se le debiera de mejorías. Más adelante, el 2 de mayo de 1562, la Chancillería ordenó designar tasadores y sometió el pleito a la justicia de Logroño que podría nombrar tercero si las nuevas tasaciones de las partes a realizar no concordaban. Como Solarte siguió insistiendo en que no podría realizar los maineles y los lazos según un diseño que se había demostrado que era falso, el monasterio consintió que se valorase el precio que habría costado realizarlos y se le descontase del precio de las mejoras. En agosto no se había alcanzado aún acuerdo alguno y la Chancillería ordenó al monasterio que atendiera la petición de Solarte y que los tasadores valoraran lo que faltaba por hacer del primer contrato y también las demasías realizadas ${ }^{29}$. El pliego consultado concluye aquí y nos priva de saber quiénes tasaron finalmente la obra y en qué cantidades lo hicieron pero se debe recordar -porque ayuda a comprender el empecinamiento del monasterio en el proceso- que en una de las tres principales sepulturas del claustro está enterrado Francisco Ordoño, natural de San Millán y oidor de la Real Chancillería de

28. "Otrosi dezimos que hemos visto una montea que se hizo para los mayneles y lazos de los arcos que corresponden a la parte del verjel del dicho claustro la qual no es la que contiene en el contrato por dos razones: la primera porque no esta conformada a la plantaforma del claustro ni firmada del abad ni de los dichos Juan Perez y Sancho de Olaso como en el contrato y condiçion lo reza sino que esta firmada del licençiado Pardo y de Francisco de la Piedra y por esto dezimos que no es la contenida en el contrato y demas de esto dezimos que no esta hecha con el repartimiento de la plantaforma porque la hemos tanteado y medido por la quenta del pitepie y no dize la una con la otra y demas desto la plantaforma no tiene mas de dos mayneles y la montea tiene tres mayneles y por estas razones no conforma con la traça primera de la plantaforma del claustro, y quanto mas que el contrato y condiçion difiere de la traça que se dio la primera vez para los dichos mayneles y lazos de los arcos como el contrato lo reza y lo declara y demas dize la condiçion que los remates de los estribos sean del romano y de seys pies de alto bien labrados en quanto a esto dezimos que los remates de la traça montea no conforman con la dicha condiçion porque antes son modernos que no romanos que por lo menos tienen mas de diez y ocho pies de alto contados por la quenta del pie".

29. ARCHV, R. Ejecutorias, C.1027.45. 
Valladolid hasta 1557. Fue padre del benedictino Diego Ordoño que llegó a ser general de la congregación en $1592^{30}$.

Como hemos visto, Pérez de Solarte no siguió la montea con el alzado de los contrafuertes y ventanas del claustro y no se puede saber si esta traza se perdió o la escondió. Desconocemos si los cambios los había acordado con fray Rodrigo de Badillo, general de la orden que visitó el monasterio en 1551. Las modificaciones eran trascendentales, como observó Vallejo, pues se suprimieron los maineles y los lazos que relacionaban el proyecto con la obra del monasterio de Santa María la Real de Nájera, aunque el adorno previsto era del romano. En su acabado actual, el claustro de San Millán de la Cogolla tiene evidentes similitudes con el del monasterio benedictino de Irache. Solarte había tasado en julio de 1546 la obra de Oyarzábal y hubo de tomar buena cuenta ya que en los estribos, en la forma de los arcos de las ventanas y en el entablamento superior sigue muy de cerca lo diseñado por el guipuzcoano. También hubo de ver avanzada la puerta de la iglesia de Irache -la Ilamada puerta Speciosa, por la antífona de San Ildefonso "Speciosa facta est" que allí se cantaba- que lleva la fecha de 1547 y se compone de modo semejante y con coincidencias llamativas en el segundo cuerpo de la Asunción y en el ático con el Padre Eterno, aunque también se encuentran en obras del ámbito de los Mutio como la portada de la iglesia de Briones.

En el claustro se mezclan elementos del Tardogótico -en las bóvedas de las capillas y en el apuntamiento de los arcos de las ventanas- con la arquitectura "del romano" en la portada, los pilares, las columnas, las molduras y los estribos. También se incorporaron algunos elementos de relativa modernidad: los tabernáculos de las esquinas del claustro concluyen en un capitel de orden compuesto, con prótomos de caballo, que se ha tomado de la lámina LXV del Libro Quarto de Sebastiano Serlio que se había publicado en Toledo en 1552 (Fig. 4). El resultado es armonioso y variado, aunque la talla tiene poco resalto y no siempre se percibe con limpieza, tal como se denunció en el pleito.

Algunos elementos se han trabajado con descuido: el monasterio denunció, con exceso, la fealdad y tosquedad de la talla de los remates o pináculos de los estribos. Podemos suponer que, como en Irache, no estaban previstos en la solución pactada de 1551, y seguramente fueron un añadido forzoso y final para intentar cumplir las condiciones del contrato original. El dibujo de su talla se corresponde con el presente en los altares de piedra y nos parece del mismo equipo de tallistas. Pero, en general, el dibujo de los motivos representados en el claustro está bien trazado, las proporciones son correctas y el ritmo decorativo es satisfactorio en una obra cuajada de multitud de elementos repartidos por claves, columnas, tabernáculos, mascarones y ménsulas. Actualmente se encuentran en

30. BerGANZA, Fray F. de, Antiguedades de España. Parte segunda. Madrid 1721, p. 321; PEÑA, J., Páginas..., pp. 24-25 y 246-247. 


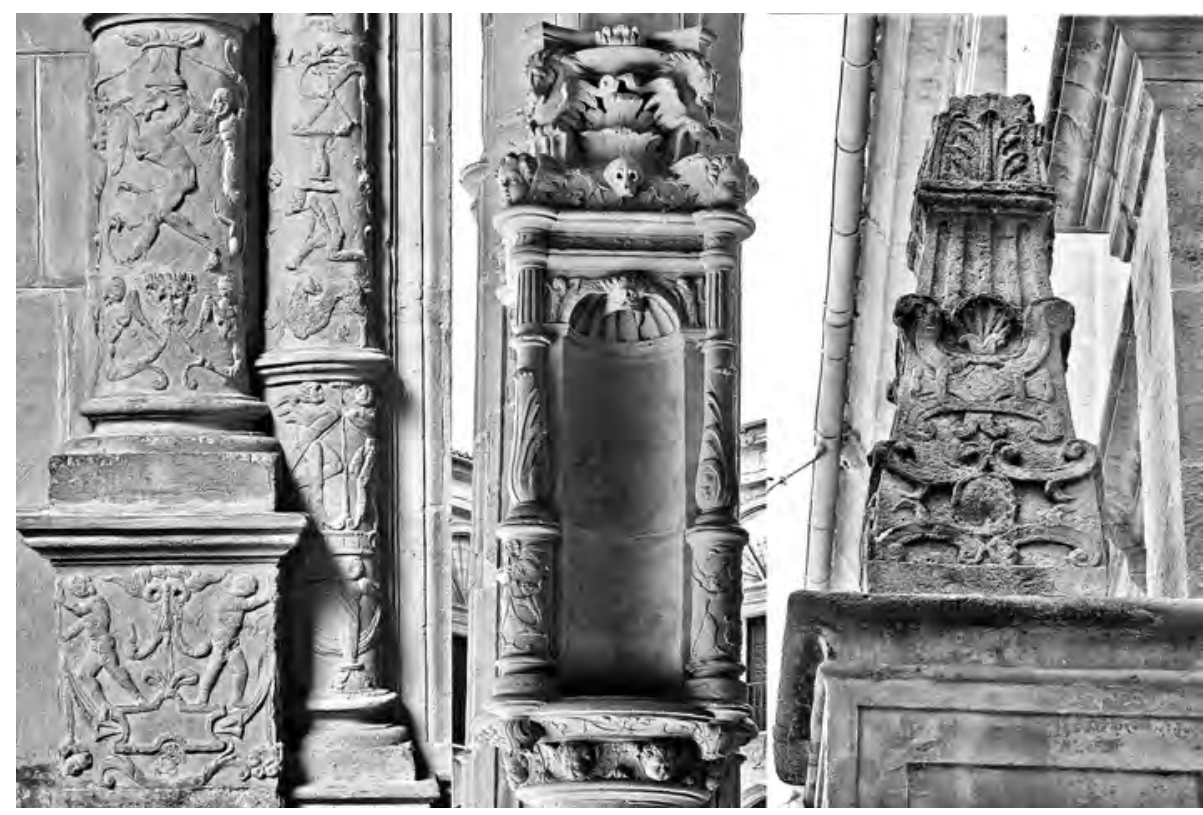

Figura 4. San Millán de la Cogolla. Elementos decorativos, de 1554 a 1559.

la portada dos ángeles tenantes de escudos de la familia López de Haro que se han reutilizado de un enterramiento anterior de finales del siglo XV. Además, encima de los capiteles que flanquean la puerta van dos escudos: uno de la abadía, aunque poco habitual, y otro de la Navarra de los Evreux.

Como en Irache, y en general en otros claustros monásticos, el adorno de las claves guarda coherencia decorativa que también se observa en las bóvedas central y sur del sotacoro -la del norte fue rehecha tras la ruina del muro exterior-. Los santos del cielo ocupan las bóvedas del claustro y se les representa en agrupaciones armónicas que giran en torno a la imagen de la clave central: Cristo resucitado, rodeado de apóstoles y evangelistas; San Gregorio Papa, acompañado de obispos; San Esteban, asistido por mártires; San Benito, por frailes; Santa Úrsula, por santas mártires; la Verónica con el sudario, por ángeles con atributos de la Pasión; Santa Catalina, por otras santas comunes en la devoción de aquel tiempo como son Santa Bárbara, Santa Águeda, Santa Apolonia y Santa María Magdalena; María con el Niño, por profetas de la Antigüedad a la manera del árbol de Jesé; un santo abad -San Millán-, por santos y santas fundadores de órdenes; María, por las virtudes; la Caridad, por santos y santas; San Benito, por santos de la orden; Cristo resucitado, por María, San Juan y los apóstoles; la paloma del Espíritu Santo, por santos y santas; los pies de Cristo en la Ascensión -se trata de una medalla que evidencia que en las bóvedas del claustro estamos ante un trasunto del cielo-, por los personajes habituales en Pentecostés; San Juan 
Bautista, por los profetas y ancianos del Apocalipsis; Cristo redentor, por un resumen selecto de los habitantes del cielo: María, San Juan, San Pedro, ángeles, profetas del Antiguo Testamento -Moisés- y apóstoles del Nuevo Testamento.

Una noticia muy sugerente es la presencia del imaginero Juan de Villarreal en 1551. Vino con el abad de San Juan de Burgos a dar orden de cómo se había de continuar la obra del claustro y ambos aportaron una traza con las dependencias monasteriales anexas al claustro. En Burgos está documentado hasta el año 1551 Juan de Lizarazu, imaginero de Villarreal (Guipúzcoa) que también es conocido en la documentación burgalesa como Juan de Villarreal ${ }^{31}$. Juan de Villarreal talló para el cabildo de la catedral de Burgos una imagen del Salvador en 1532 que se dispuso en el viejo crucero. Entre 1534 y 1537 realizó, para adorno del mismo lugar, representaciones de los cuatro evangelistas y los cuatro doctores de la Iglesia. También para la catedral hizo

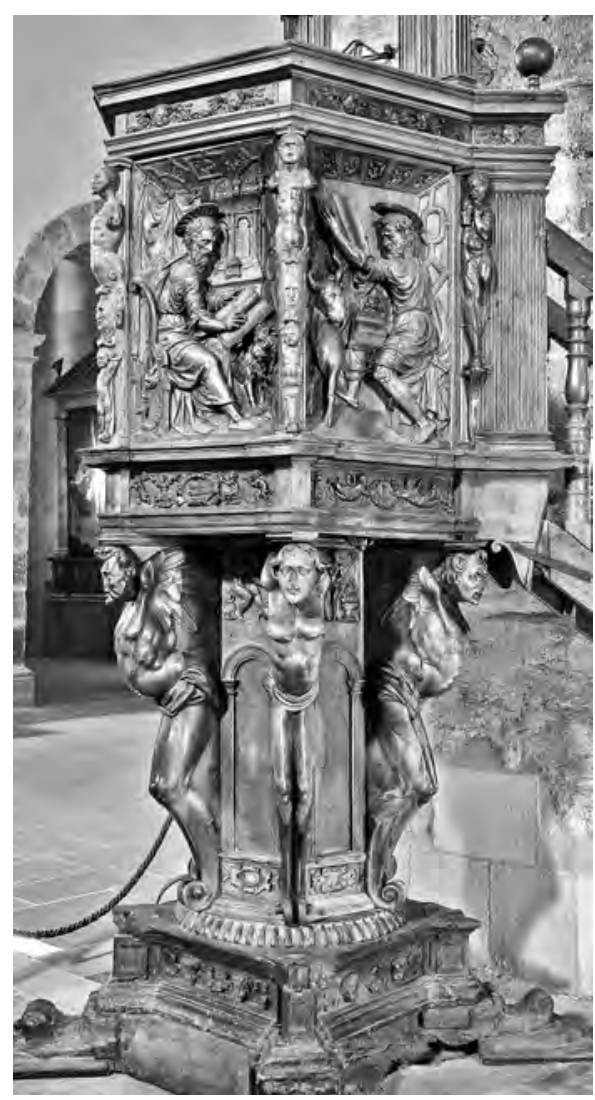

Figura 5. San Millán de la Cogolla. Púlpito de la iglesia, hacia 1555. una figura de San Sebastián y las andas para transportarla, y unas filateras para la capilla de Santiago ${ }^{32}$. En agosto de 1540 Lizarazu contrató ${ }^{33}$ con el canónigo Juan Martínez de San Quirce la hechura de un retablo de imaginería para la capilla de San Antón o de la Anun-

31. IBÁÑ̃Z PÉREZ, A. C., "El escultor Juan de Lizarazu y el retablo de la capilla de la Anunciación en la catedral de Burgos", Boletín del Seminario de Estudios de Arte y Arqueología 39 (1973), pp. 189-201; IBÁÑEZ PÉREZ, A. C., "El escultor Juan de Lizarazu y el retablo mayor de Foncea (Logroño)", Berceo 96 (1979), pp. 61-72; BARRÓN GARCíA, A. A. y RUIZ DE LA CUESTA, M. a P., "Diego Guillén, imaginero burgalés (1540-1565)", Artigrama 10 (1993), pp. 236 y 243-244. En 1538 y en 1539 en la documentación de un pleito por la tasación de un retablo para Valtierra de Riopisuerga (Burgos), se denomina al escultor alternativamente Juan de Lizarazu y Juan de Villarreal; ARCHV, PI. Civiles, Pérez Alonso (F), 424.6.

32. Archivo Catedral de Burgos, Libro de fábrica no 1, 1514-1562, f. 54 r y v.

33. También, LÓPEZ MATA, T., La catedral de Burgos. Burgos 2008 [reed.], p. 331. 


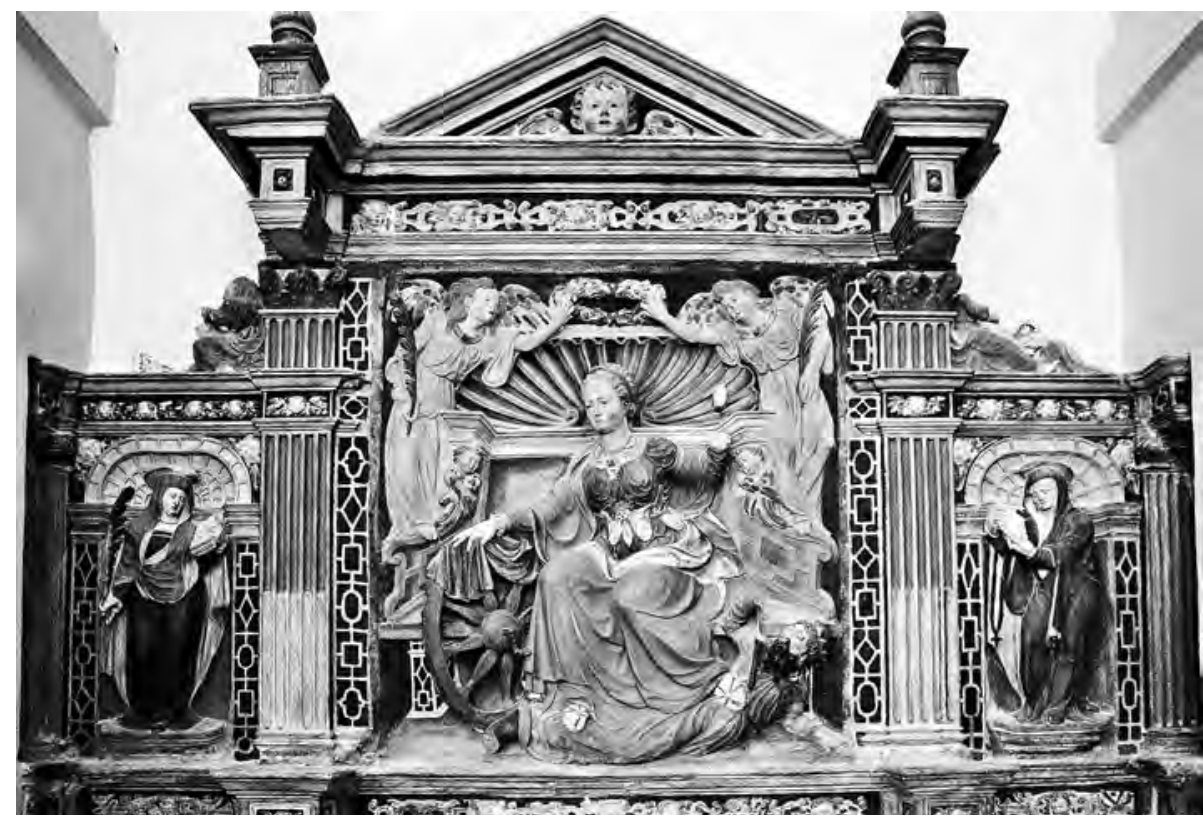

Figura 6. San Millán de la Cogolla. Retablo de Santa Catalina en el claustro alto, h. 1555.

ciación de la catedral burgalesa que muestra figuras esbeltas y movidas. Lamentablemente no se conservan sus últimos encargos, por lo que no se conoce la evolución de su estilo: así un retablo de "media talla" para la iglesia de Santa Clara de Burgos que contrató el 1 de junio de 1551 con Juan de Carboneras, alcalde mayor de las Huelgas. Con anterioridad, el 15 de septiembre de 1547, había convenido hacer en piedra de Hontoria o de Atapuerca la sepultura de Diego de los Ríos e Inés de Miranda que debía colocarse en la iglesia del monasterio de San Francisco de Burgos ${ }^{34}$. Estos documentos evidencian que Juan de Lizarazu o Juan de Villarreal trabajaba la madera y la piedra. Como Solarte declaró que en la portada de la iglesia de San Millán y en las claves de las bóvedas había trabajado el oficial predilecto del monasterio, podemos suponer que fue él, a la espera de otra documentación. Tal vez correspondan a su mano y a su taller el púlpito de madera de la iglesia (Fig. 5), los remates de los contrafuertes del claustro, el grupo de la Asunción de la portada y los tres altares de las esquinas del claustro -seguramente dos de estos altares se corresponden con los conservados en el claustro alto: el de Santa Catalina entre dos monjas santas (Fig. 6) y el de un santo obispo o abad, posiblemente San Benito, entre los

34. BARRÓn GARCíA, A. A. y RUIZ DE LA CUESTA, M. ․ P., “Diego Guillén...”, p. 243. 
santos Juanes ${ }^{35}$-. En las obras citadas observamos algunos estilemas comunes, especialmente en el repertorio decorativo. Un equipo distinto y de ámbito riojano talló el resto de la portada y la decoración de columnas, tabernáculos y ménsulas de los tramos del claustro.

Con todo, se sabe de otro Juan de Villarreal (ca. 1517-1584) (16 $^{36}$ que trabajó en Pamplona y fue arquitecto y veedor del obispado al menos desde 1563, aunque en 1556 se le denomina entallador en el contrato de la portada del hospital de Nuestra Señora de la Misericordia en Pamplona que se adorna con figuras fantásticas de carácter expresivo propias del estilo manierista que abunda en el Norte de España a mediados del siglo ${ }^{37}$. En enero de 1566 Villarreal estuvo precisamente en Calahorra para analizar la traza que Pérez de Solarte había proporcionado para ampliar la cabecera de la catedral ${ }^{38}$.

35. Sobre estos altares, identificados como Santa Catalina y San Ildefonso, ARRÚE UGARTE, B., "Apuntes sobre el patronazgo y conservación del patrimonio artístico del monasterio benedictino de San Millán de la Cogolla en La Rioja", Los monasterios de San Millán..., p. 138.

36. TARIFA CASTILLA, M. ․ J., "Juan de Villarreal: tradición e innovación en la arquitectura navarra del siglo XVI", Príncipe de Viana 61 (2000), pp. 617-656.

37. TARIFA CASTILLA, M.․‥, "Juan de Villarreal...", pp. 622-623.

38. CALATAYUD FERNÁNDEZ, E., Arquitectura..., T. I, p. 566. 